\title{
Research Paper \\ Identifying and Comparing the Learning Styles based on Gender, Syllabus and Educational Level with Emphasis on Cluster Analysis
}

\section{Seyed Bahaddin Karimi ${ }^{1}$, Yousef Adib $^{* 2}$, Firouz Mahmoudi ${ }^{3}$, Rahim Badri Gargari ${ }^{4}$}

1. Ph.D. Student of Curriculum Planning, Faculty of Educational Sciences and Psychology, Tabriz University, Iran

2. Professor, Department of Educational Sciences, Faculty of Educational Sciences and Psychology, Tabriz University, Iran

3. Associate Professor, Department of Educational Sciences, Faculty of Educational Sciences and Psychology, Tabriz University, Iran

4. Professor, Department of Psychology, Faculty of Educational Sciences and Psychology, Tabriz University, Iran

Citation: Karimi SB, Adib Y, Mahmoudi F, Badri Gargari R. Identifying and comparing the learning styles based on gender, syllabus and educational level with emphasis on cluster analysis. Quarterly Journal of Child Mental Health. 2020; 7(3): $193-204$.

\section{http://dx.doi.org/10.52547/jcmh.7.3.16}

\section{A R T I C L E I N F O}

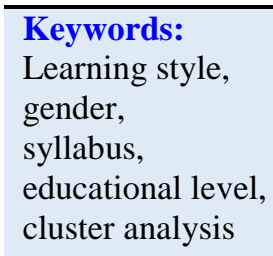

Received: 1 Aug 2018

Accepted: 16 Oct 2018

Available: 7 Dec 2020

\section{A B S T R A C T}

Background and Purpose: The factors affecting learning are very wide and it is very important to identify these factors in solving the problems in the educational system. Learning style is one of these factors. Hence, present study was conducted to identify and compare the learning styles based on the gender, the syllabus and the educational level by using cluster analysis.

Method: This study was an applied research in its goal and a descriptive-survey study in its methodology. The study population included all the primary school students of grades 4, 5 and 6 in West Azerbaijan in the academic year 2017-2018. Among which, a sample of 1961 students $(928$ boys and 1033 girls) was selected by multi-stage clustering and completed VARK Learning Style Questionnaire (1998). Data were analyzed by cluster analysis and Chi-square.

Results: The results of cluster analysis indicated five learning styles in the students, including the visual, auditory, reading/writing, kinesthetic and multiple styles. Among which, the multiple style was the most prevalent, while the auditory style was the least prevalent one. Results also showed that learning style is different according to the gender $\left(\mathrm{P}<0.01 ; \mathrm{X}^{2}=16.87\right)$ and educational level $(\mathrm{P}<0.05$ ; $\left.\mathrm{X}^{2}=18.320\right)$, but no significant difference was found in the learning style of the students based on the syllabus.

Conclusion: Based on the results of this study, students prefer using multiple learning styles. Learning styles are different based on the gender and educational level, however no significant difference was found according to the syllabus. Accordingly, identifying the learning style of the students can help teachers in teaching more efficiently and decreasing the learning problems.

\footnotetext{
* Corresponding author: Yousef Adib, Professor, Department of Educational Sciences, Faculty of Educational Sciences and Psychology, Tabriz University, Iran.

E-mail addresses: Yousef_adib@yahoo.com
}

2476-5740/ (C) 2019 The Authors. This is an open access article under the CC BY-NC-ND license (https://creativecommons.org/licenses/by-nc-nd/3.0/). 


\section{شناسايیى و مقايسه سبكىهاى يادكيرى بر اساس جنسيت، موضوع درسى، و هايه تحصيلى با تأكيد بر روش تحليل خوشهاى برى}

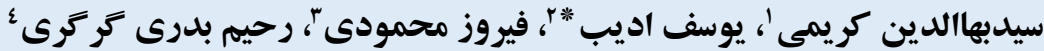

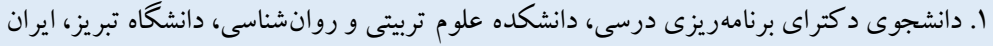

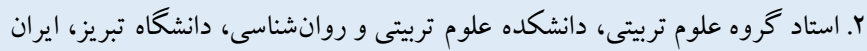

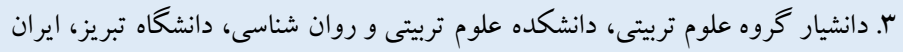

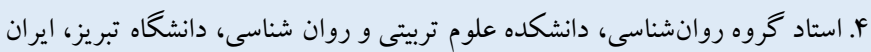

\section{جكيله}

زمينه و هدف: عوامل مؤثر بر يادگيرى بسيار گسترده و وسيع بوده و شناسايى اين عوامل در رفع مشكلات و نارسايىهاى موجود در

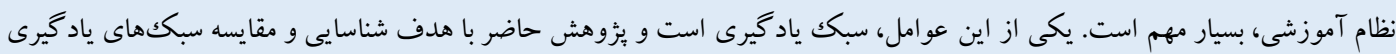
بر اساس جنسيت، موضوع درسى، و يايه تحصيلى با استفاده از روش تحليل خوشهاى انجام شد. روش: اين يُوهش از نظر هدف، كاربردى و از نظر روششناسى، توصيفى- ييمايشى است. جامعه آمارى اين مطالعه شامل تمامى

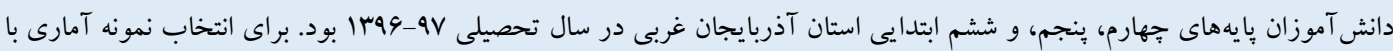

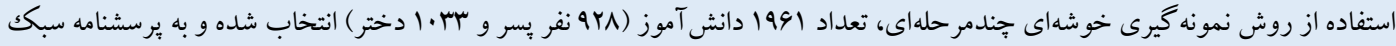
ياد گيرى وار كك (1991) ياسخ دادند. دادههاى جمع آورى شده با استفاده از آزمون تحليل خوشهاى و خى دو وارسى و تحليل شدند.

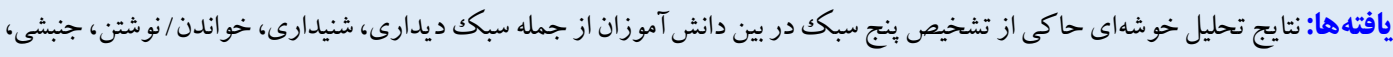

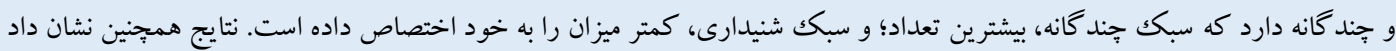

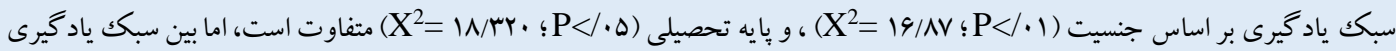
بر اساس نوع درس (موضوع درسى)، تفاوت معنادارى مشاهده نشد.

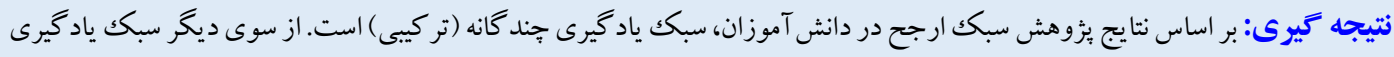
بر اساس جنسيت و بايه تحصيلى، متفاوت است؛ اما بر اساس نوع درس (موضوع درسى)، تفاوت معنادارى در بين سبككها مشاهده نشده است. بدين ترتيب، آكاهى از نوع سبك ياد كيرى دانش آموزان جهت تدريس مؤثر معلمان و كاهش مشكلات ياد كيرى، مهم است.
مشخصات مقاله

سبك ياد گيرى، جنسيت،

موضوع درسى،

بايه تحصيلى،

تحليل خوشهاى

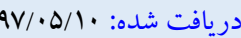
يذيرفته شده: QV/PV/FF منتشر شده: 99//V

* نويسنده مسئول: يوسف اديب، استاد گروه علوم تربيتى، دانشكده علوم ترييتى و روانشناسى، دانشكاه تبريز، ايران.

Yousef_adib@yahoo.com رايانامه

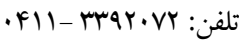


سبكك يادگيرى مى تواند بيامدهاى مهمى براى آموزش داشته باشد، زيرا

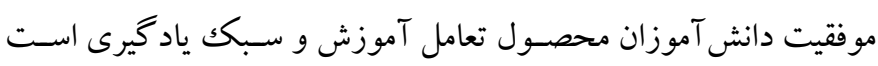

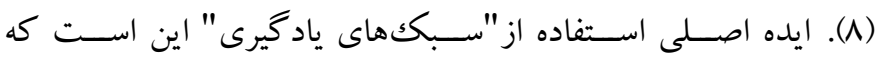

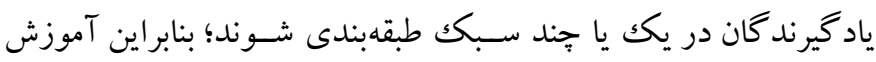

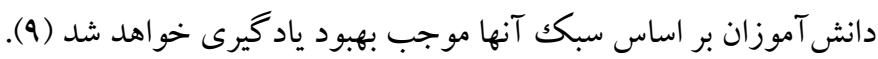

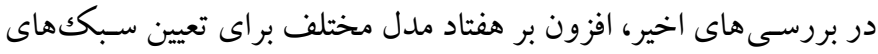

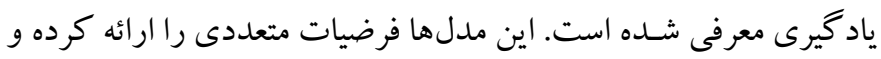

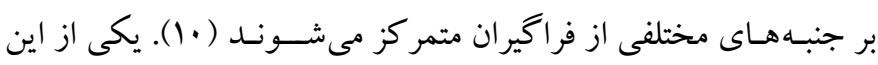

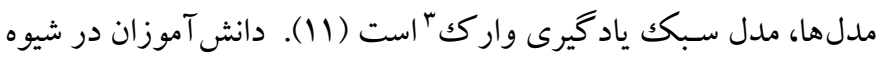
واركك بر اسـاس شــيوه تعامل و ياســخ دادن به محيط ياد كيرى به جههار

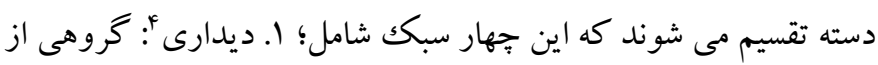

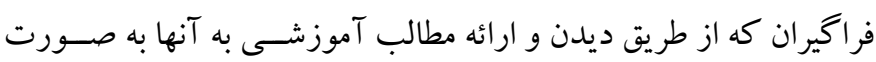
نمايش (نمودار، شكل ها و تصاوير)، كه همراه با توضيح بيشتر باشد، بهتر

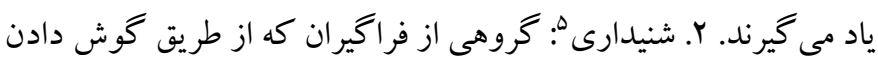

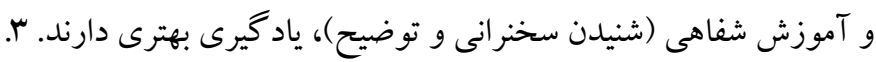

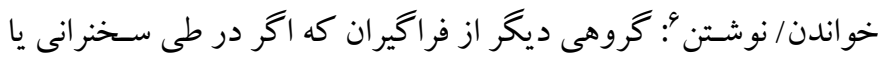

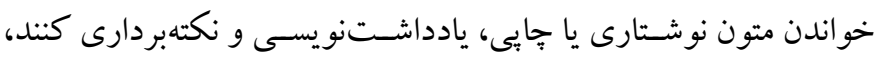

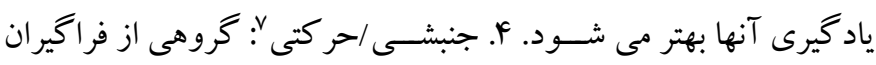

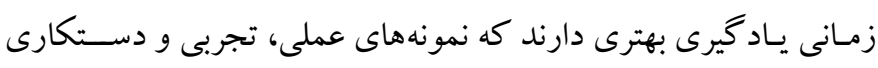

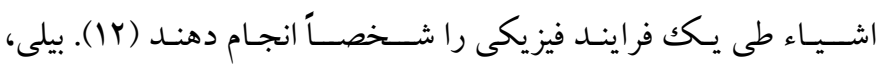

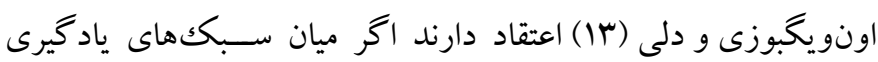

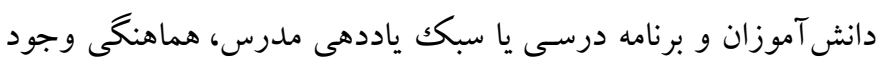

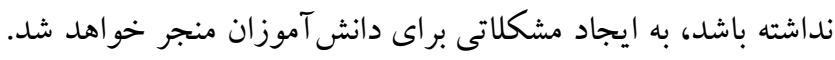

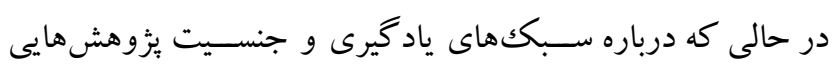
انجام شده است، اما در ارتباط با سبكك ياد گيرى با موضوع درسى و و يايه

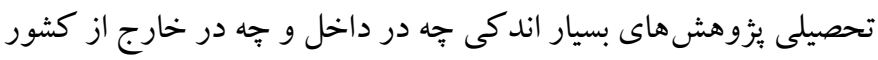

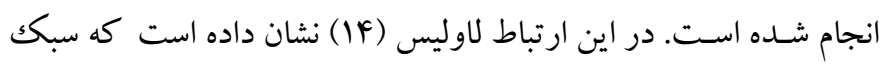

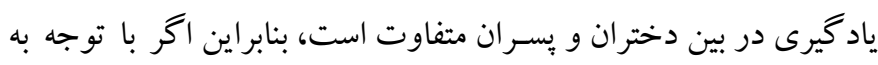

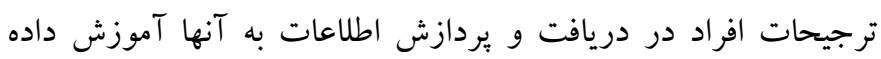

5. Aural

6. Read/write

7. Kinesthetic
مقلدمه

افراد در موقعيت يكســان، متفاوت ياد مى كيرند كه شــايد مهم ترين دليل آن ســبكهاى يادگيرى' متفاوت آنان باشــــ اين

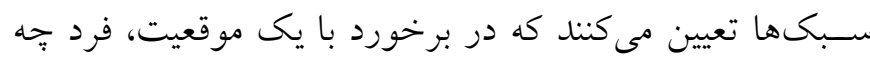

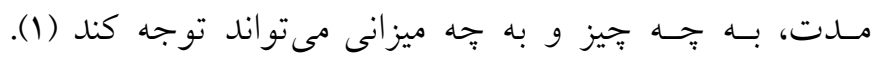

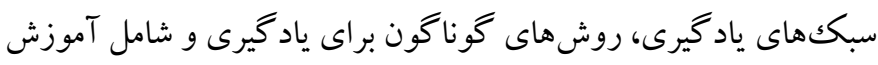

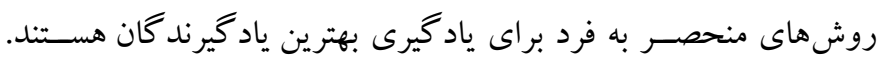

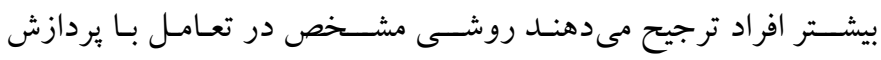

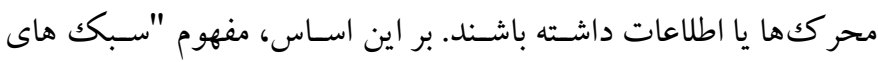

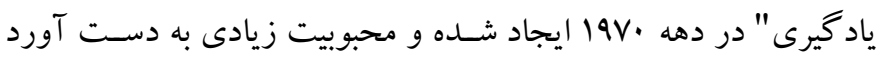

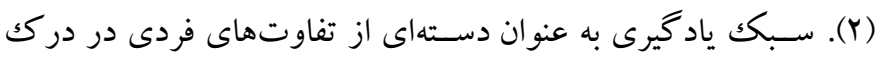

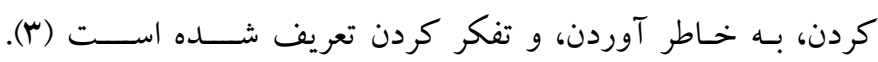

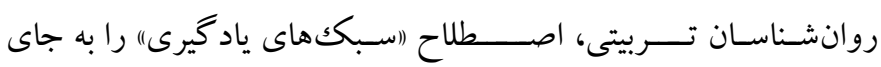

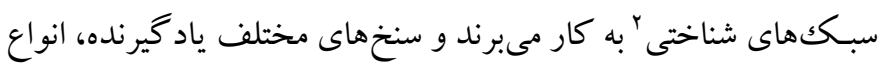

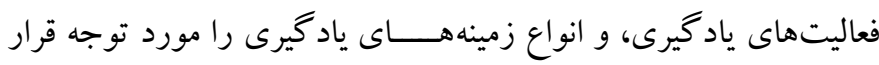

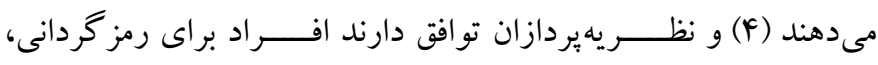
يردازش و دستكارى اطلاعات، سبككهاى متفاوتى دارند كه اساساً مستقل از هوش است (ه).

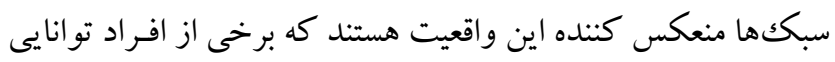
بيشترى در استفاده از برخى فرايندهاى يادگيرى دارند. اين تو انايىها در

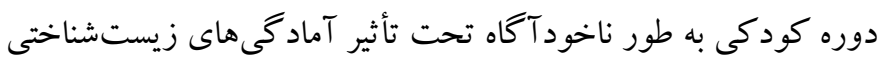

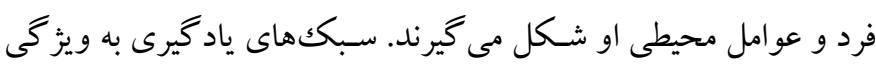

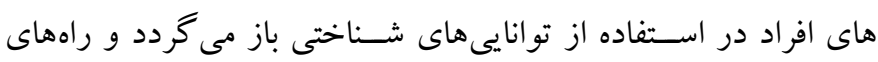

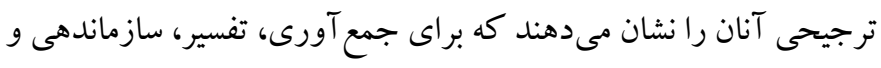

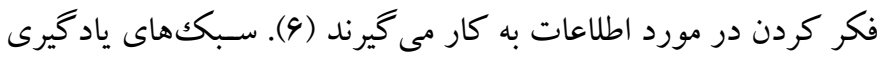

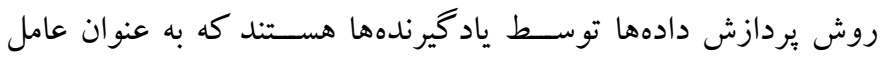

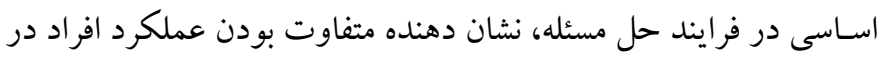

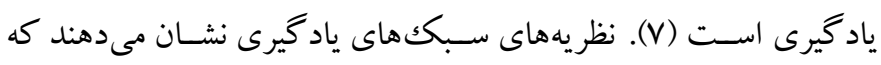

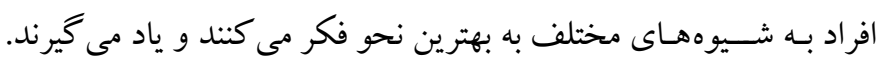

1. Learning styles

2. Cognitive styles

3. Vark

4. Visual 
سـالهاى اخير، ياد گيرى بر مبناى شـايستخىى' و تعامل ياد گيرى ب باشد.

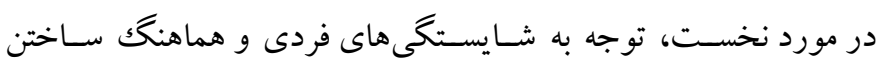

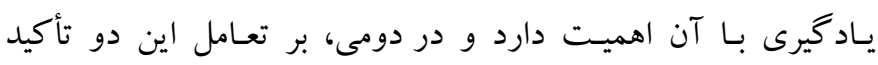

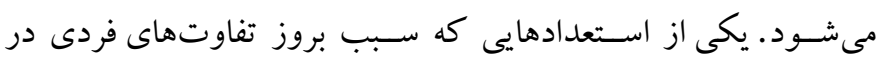

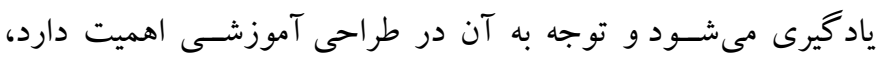

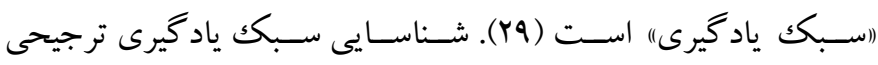

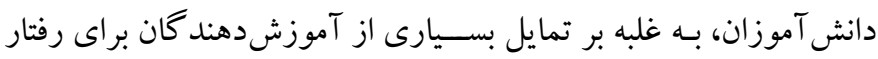

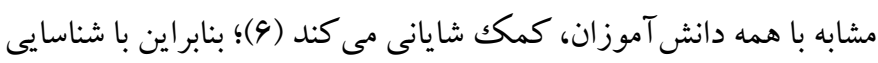

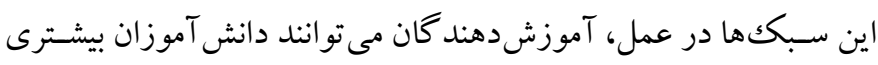

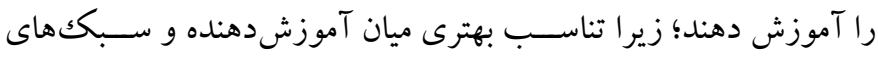

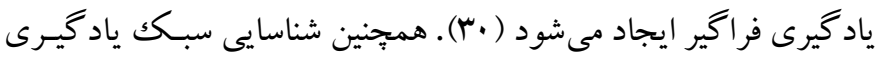

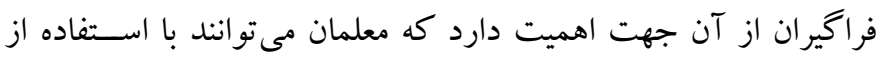
روشهاى تدريس متناسـب، باعث يادگيـــــى بهتر آنان شــوند (.1).

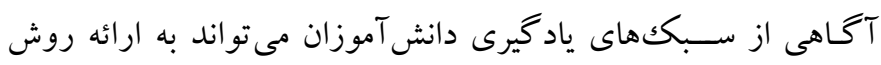

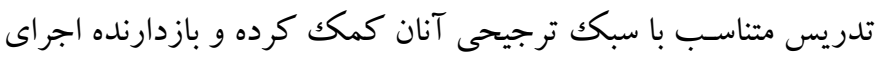
يكك روش تدريس همسان، براى همه دانش آموزان توسط مدرسان شود

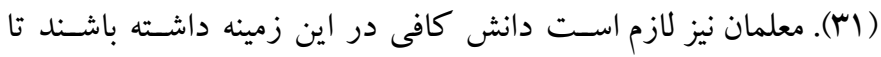

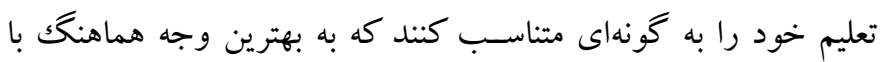

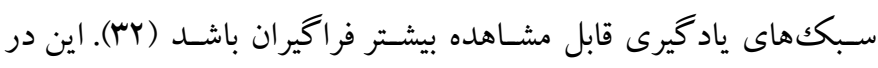

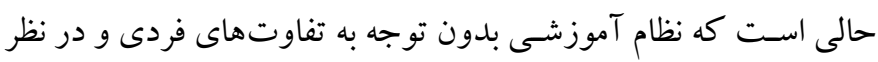

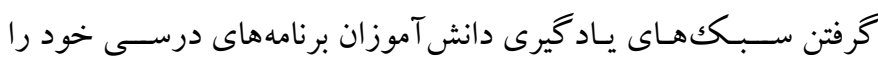

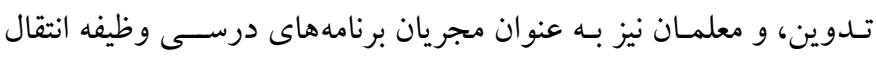

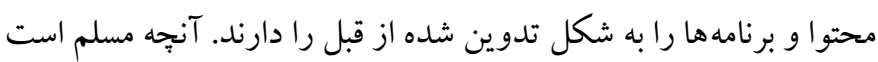

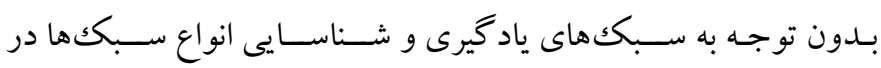

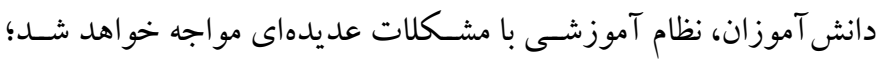

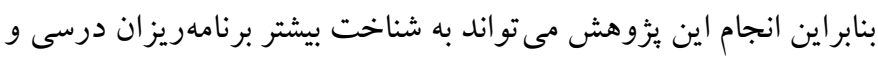

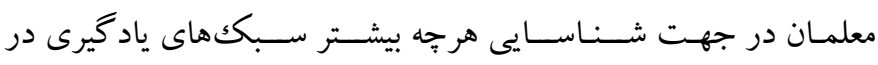

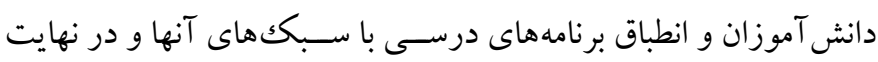
توجه به رعايت اصل تفاوتهاى فردى كمكك شايانى كند.

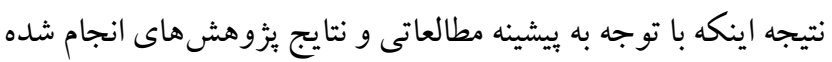

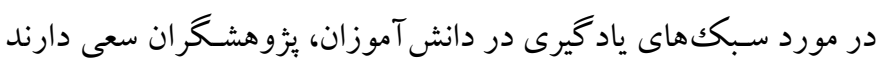

شـود، بيشــــت تحصـيلى آنها افزايش مىيـابد. همجنين كوكى، سـالمونسـن، رولى و ديويدســون (1))، جيمز، ديمور و توماس (19)،

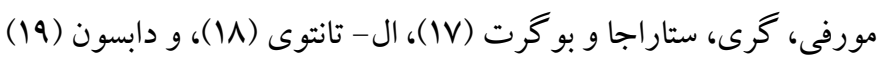

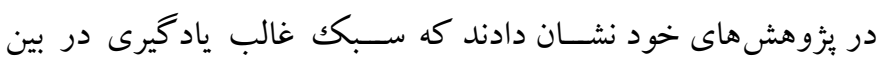

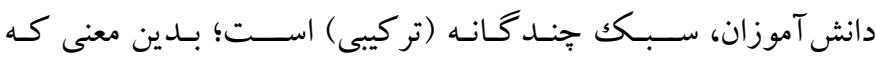

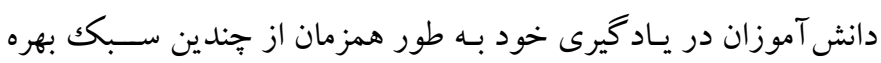

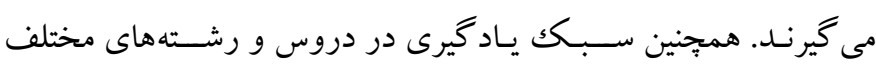

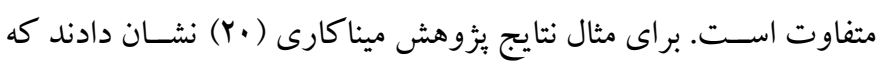

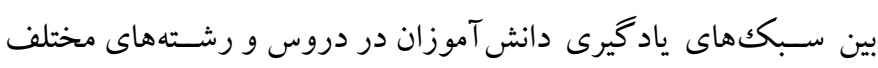

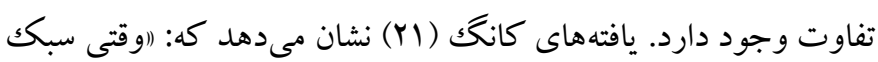

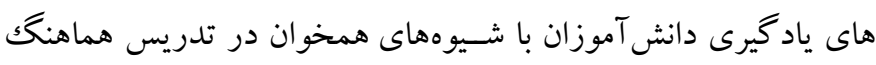

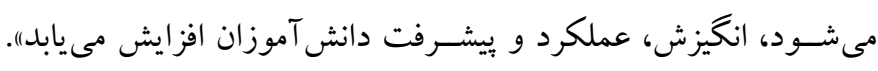

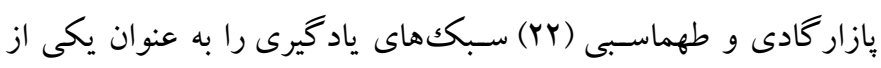

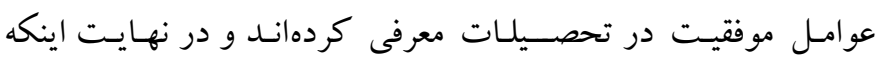

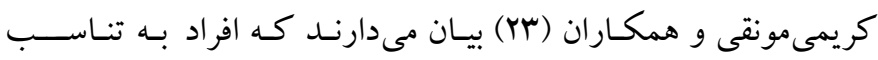

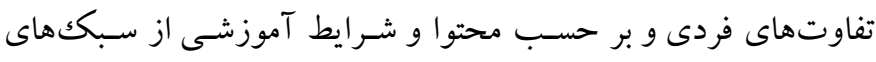

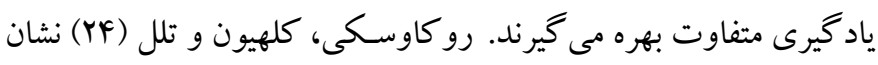

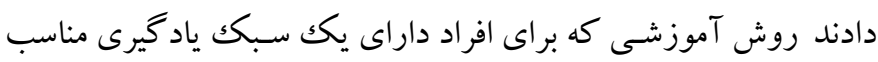

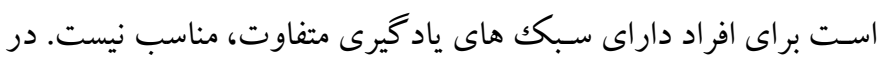

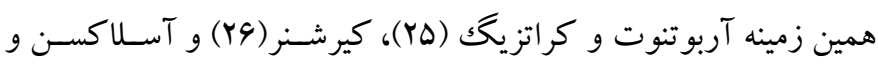

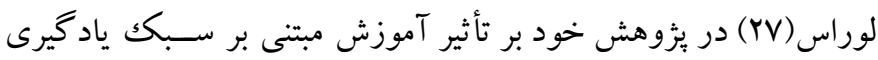
تأكيد دارند. با توجه به نظريههاى شـناختى، امروزه در موضسوع ياد كيرى، فردى

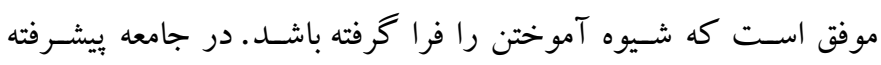

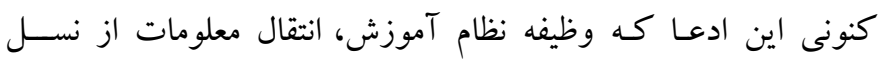

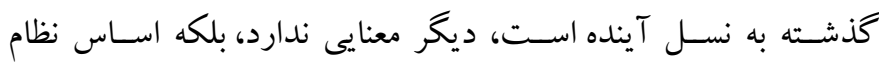

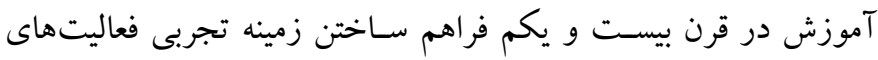

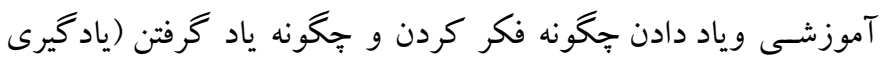

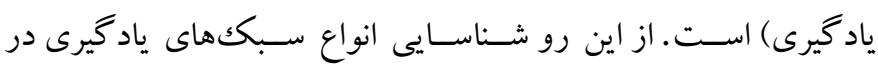

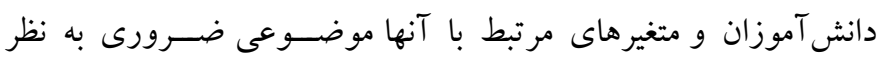

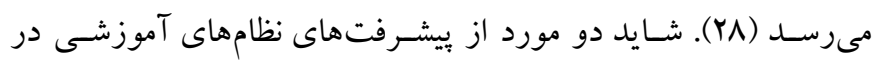


جامعه آمارى شـامل تمامى دانش آموزان دختر و يســر پِايههاى جهارم،

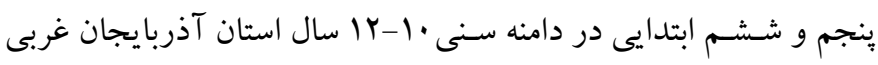

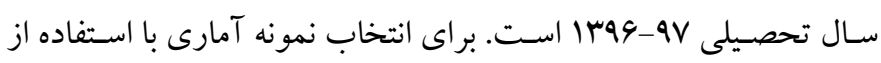

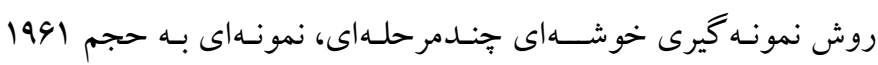

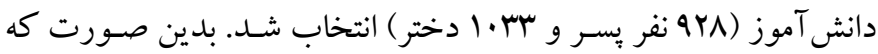

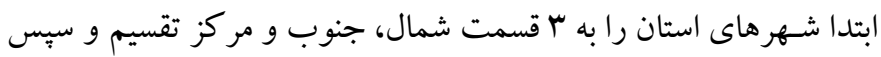

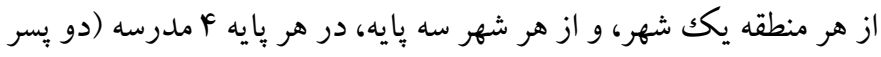

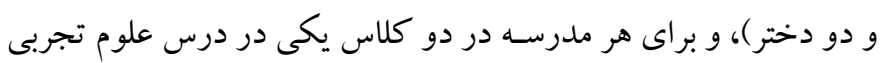

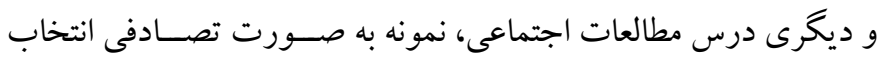

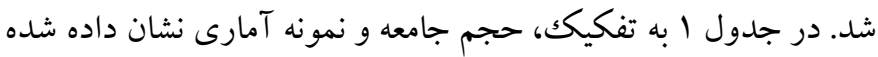

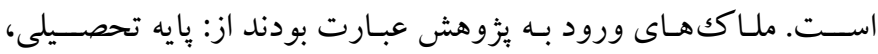
كلساس هاى با دروس علوم تجربى و مطالعات اجتماعى، رضـايت كامل

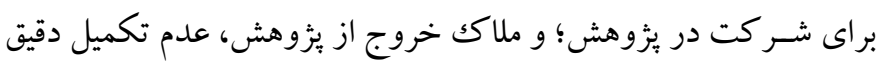
و كامل برسشنامه ها بود.
در اين يُزوهش با شـناسـايى نوع سبكهاى ياد گيرى در دانش آموزان، و

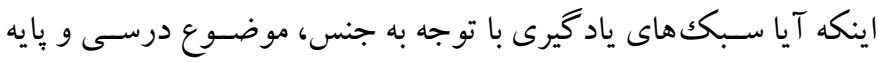

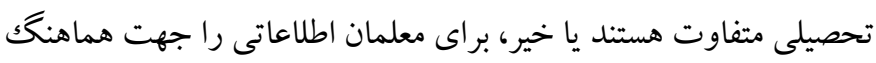

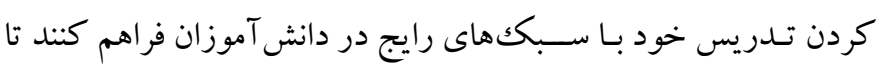

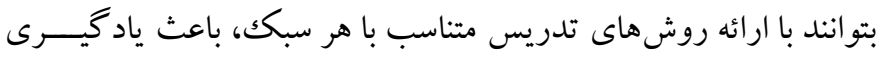
بهتر و عميق تر در دانش آموزان و بهبود كيفيت تدريس و آموزش شوند. تهن. بدين ترتيب در اين ئزوهش به بررسـى و مقايسـهـ توزيع آمارى جهار

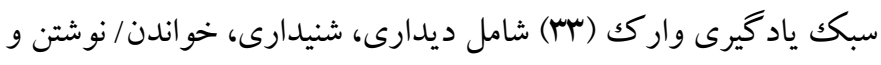

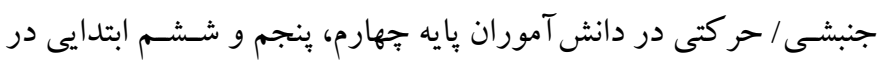

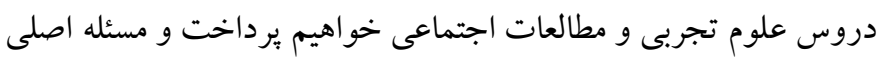

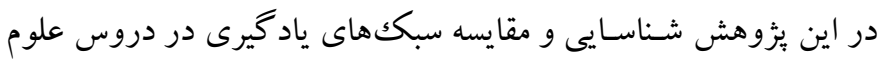
تجربى و مطالعات اجتماعى بِايه جهارم، بنجم و ششم ابتدايى است.

روش الف) طرح يزوهش و شــر كت كنند كان: اين يزوهش از حيث هدف

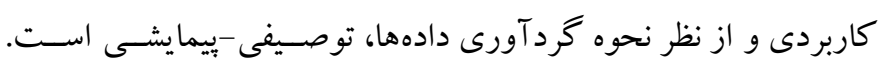

جدول 1: نمونه آمارى به تفكيك جنسيت و ساير شاخصها

\begin{tabular}{|c|c|c|c|c|c|c|}
\hline جنسيت & تعداد نمونه به تفكيك & كلاسها & تفكيكك مدرسه & هايه & نام شهر & وضعيت جغرافيايى \\
\hline دختر MVV & rrr & م كلاس & F Fل مدرسه & جهارم & & \\
\hline \multirow[t]{2}{*}{ 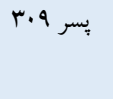 } & rl. & 1 كلاس & F Fل مدرسه & ينجم & سلماس & شمال \\
\hline & rif & 1 كلاس & F Fل مدرسه & ششم & & \\
\hline دختر & YYF & 1 كلاس & F Fل مدرسه & جهارم & & \\
\hline \multirow[t]{2}{*}{ بسر } & ris & 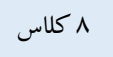 & F أ مدرسه & ينجم & بو كان & جنوب \\
\hline & rII & 1 كلاس & F Fل Fل Fرسه & ششم & & \\
\hline دختر IFF & rma & م كلاس & F Fل مدرسه & جهارم & & \\
\hline \multirow[t]{2}{*}{ يسر } & $r \cdot \Delta$ & 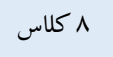 & 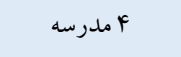 & ينجم & اروميه(ناحيه () & مركز \\
\hline & rYF & 1كلاس & F Fدرسه & مشم & & \\
\hline دختر سM.1 & 1991 & vr & ra & 9 9 بايه & با شهر & جمع \\
\hline
\end{tabular}

شــد بر سـه اصـل اسـتوار اسـت: ا. هر كسـى توانايى ياد گيرى دروس مدرسـه اي را دارد، اما هر كسى شيوه خاص خود را دارد؛ ب. هنگامى كه شيوهاى ياد گيرى متفاوت ياد گيرند گان مورد توجه قرار مى گيرد، انخيزه ياد گيرى آنان افزايش مىيابد؛ و ل. محتواى آموزشسى به وسـيله
ب) ابزار جهت تعيين و تشخيص نوع سبك ياد گيرى دانش آموزان در اين بثروهش از يرسـشـنامه استاندارد واركك (1991) استفاده شده است. اين برسشنامه كه به وسـيله دانشـاه لينكلن نيوزيلند در سـال 991 ابا 19 گويه تدوين 
ج) روش اجر ا: بعـد از دريـافت نامه از دانشــاه تبريز جهت معرفى به

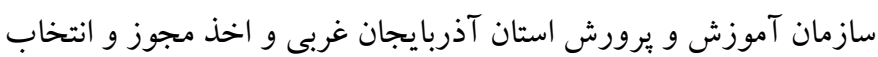

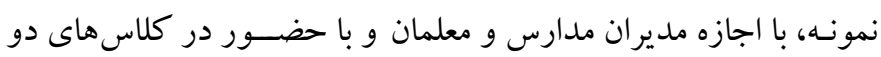
درس علوم تجربى و مطالعات اجتماعى، برسشنامهاى يُروهش در مر اختيار

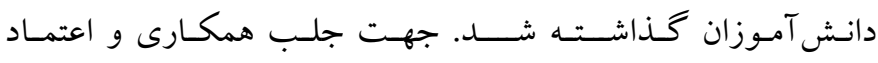

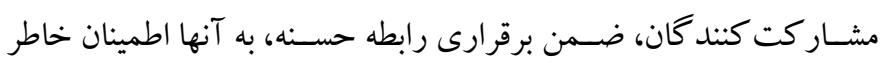
داده شـد كه اطلاعات يُزوهش محرمانه باقى خواهد ماند ماند. از آنها خواسته

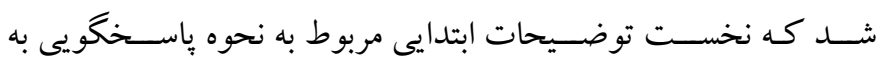

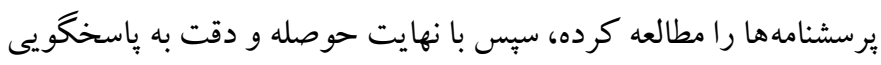

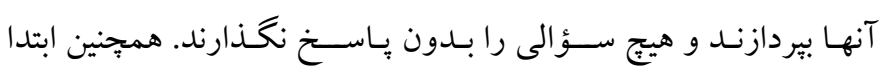

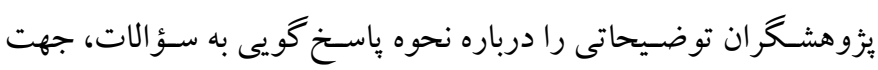

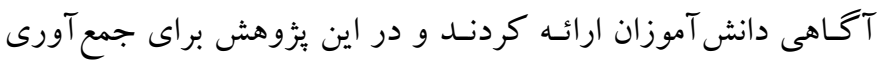

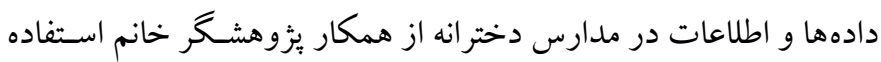

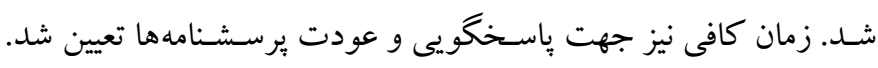

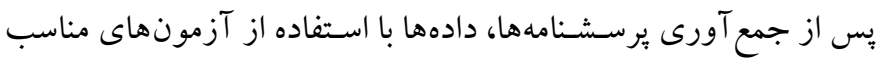

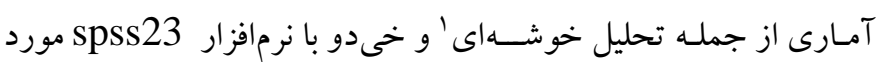
تحليل قرار خرفتند.

\section{يافتهها}

براى بررسى وضعيت سبككهاى يادگيرى دانش آموزان از روش تحليل

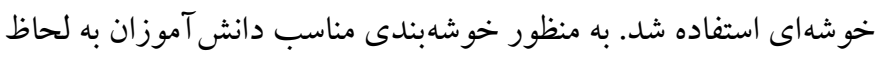

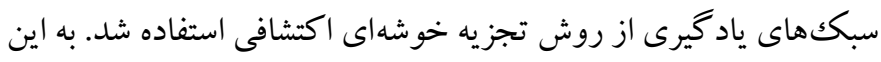

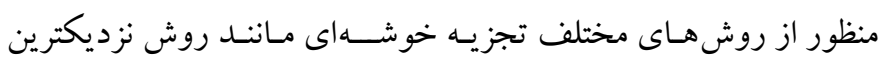

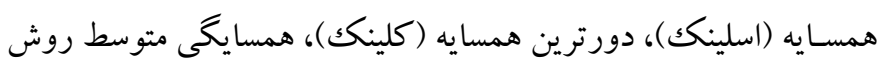

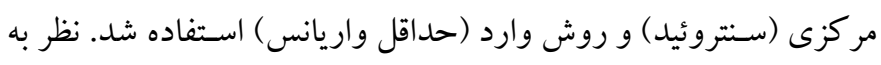
اين كه روش وارده، از نتايج منطقى ترى برخوردار است و افر اد را به طور

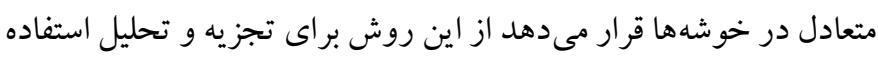

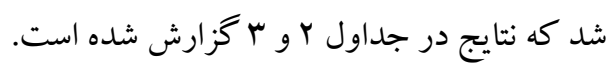

اسـتفاده از نيروى حواس و ادراكات مختلف به بهترين نحو ياد گرفته

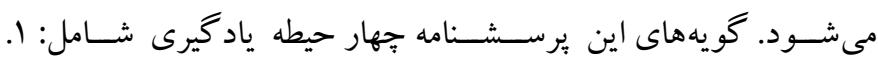

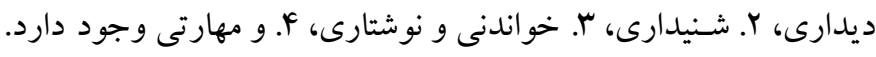

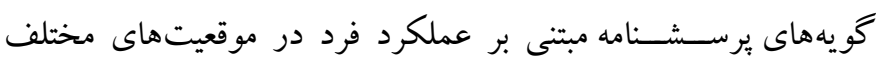

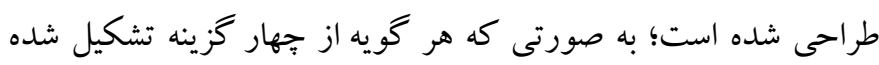

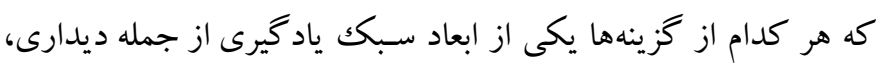

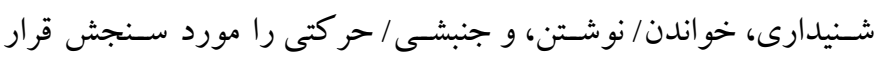

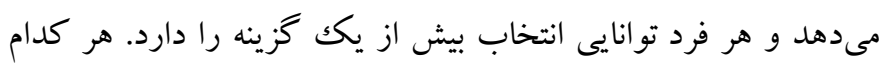

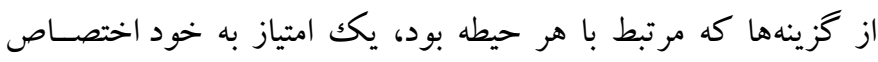

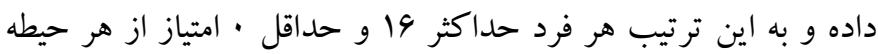

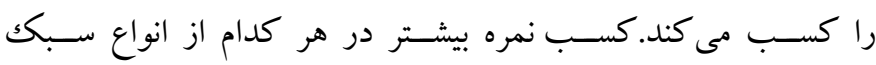

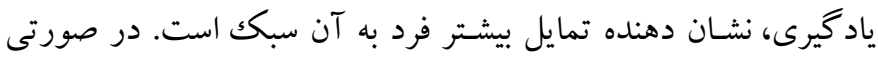

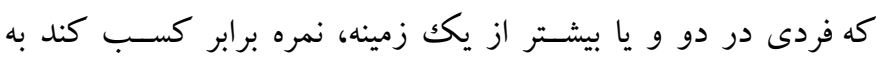

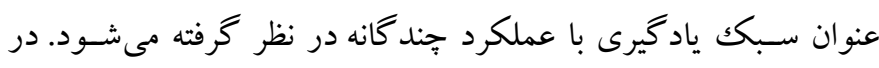

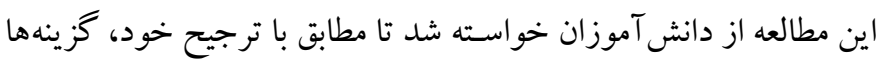

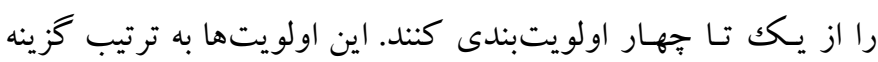

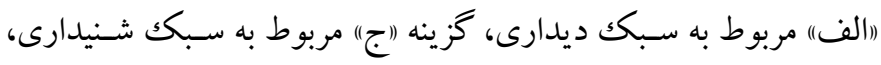

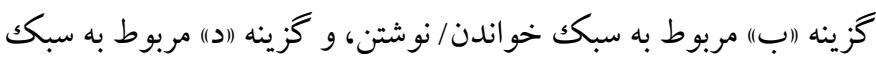

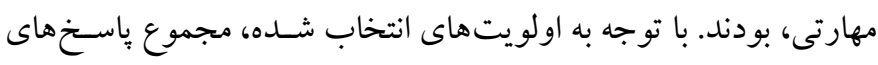

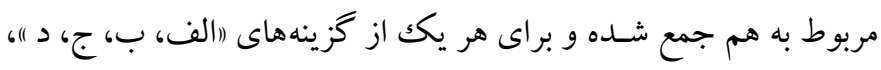

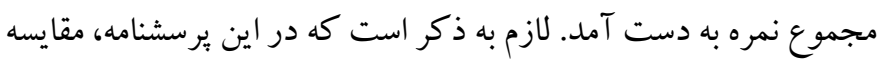
نمرات هر گزينه، اولويت آن سبك را مشخص مى كند (سب). اين يرسـشـنامه توسط وارك (1991) هنجاريابى شــ (9). همبِنين شـاخصهاى روانسـنى آن در داخل كشـور نيز توسط امينى، زمانى و

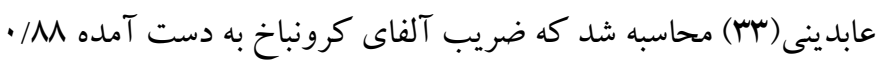

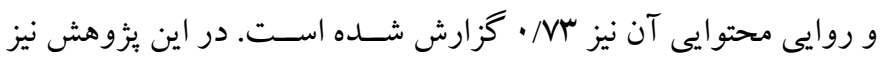

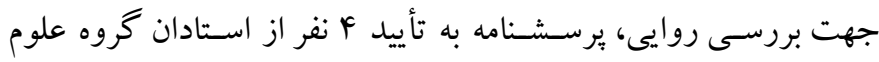

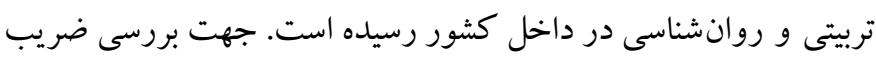

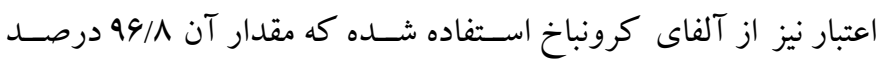
بر آورد شده است. 
جدول r: خوشهها يا طبقات تشكيل يافته از تحليل خوشهاى

\begin{tabular}{|c|c|c|c|c|c|}
\hline درصد & تعداد & انحراف استاندارد & ميانكين & سبك ها & خوشه \\
\hline \multirow{5}{*}{$\% 11 / 9$} & \multirow{5}{*}{ rrA } & $1 / 99$ & $\Delta / 94$ & ديدارى & \multirow{5}{*}{1} \\
\hline & & $1 / .9$ & $1 / F r$ & شنيدارى & \\
\hline & & $1 / 10$ & $1 / 94$ & خو اندن/ نوشتن & \\
\hline & & - /qVIr & $1 / r r$ & جنبشى & \\
\hline & & $r / Y F$ & $1 / 49$ & تركيبى & \\
\hline \multirow{5}{*}{$\% 1 . / 9$} & \multirow{5}{*}{ rir } & $\cdot / / F A F$ & . & ديدارى & \multirow{5}{*}{ r } \\
\hline & & $1 / V r$ & $r / 99$ & شنيدارى & \\
\hline & & $\cdot / 4 \Delta 9 \Delta$ & $\cdot / \mu \cdot \Delta$ & خواندن/ نوشتن & \\
\hline & & .191 .4 & . TYAS & جنبشى & \\
\hline & & $1 / \Delta 9$ & $1 / \pi r$ & تر كيبى & \\
\hline \multirow{5}{*}{$\% \mathrm{rV} / \mathrm{V}$} & \multirow{5}{*}{$\Delta F F$} &.$/ 9 \mathrm{VQV}$ & $1 / 4$. & ديدارى & \multirow{5}{*}{$r$} \\
\hline & & 1/90 & $r / q 1$ & شنيدارى & \\
\hline & & $1 / \Delta \Lambda$ & $F / F V$ & خواندن/ نوشتن & \\
\hline & & $1 / 09$ & $|/ r|$ & جنبشى & \\
\hline & & 年/ & 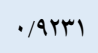 & تركيبى & \\
\hline \multirow{5}{*}{$\% 19 / 9$} & \multirow{5}{*}{ rYq } & . $/$ AMI & $1 / 19$ & ديدارى & \multirow{5}{*}{ r } \\
\hline & & $1 / 4 F$ & 每 & شنيدارى & \\
\hline & & $1 / 1 r$ & $1 / \Delta \Lambda$ & خواندن/ نوشتن & \\
\hline & & $1 / 9$. & $\Delta / \wedge F$ & جنبشى & \\
\hline & & 年 & ITrY & تركيبى & \\
\hline \multirow{5}{*}{ \% } & \multirow{5}{*}{90.} & $1 / 19$ & $1 / \Gamma \Lambda$ & ديدارى & \multirow{5}{*}{$\Delta$} \\
\hline & & $1 / 99$ & $r / T)$ & شنيدارى & \\
\hline & & ./৭४४. & $r / A)$ & خواندن/ نوشتن & \\
\hline & & $1 / 9 V$ & $r / F I$ & جنبشى & \\
\hline & & $1 / 9$. & $r / \cdot v$ & تر كيبى & \\
\hline
\end{tabular}

نمرات بالا و در بقيه سـبك ها داراى نمرات پإيين هستند. نتايج در جدول rابه طور كلى گزارش شده است.

جدول "ّ: جدول توزيع فراوانى خوشه ها به تفكيك

\begin{tabular}{|c|c|}
\hline تعداد افراد & خوشهها \\
\hline YYA & ديدارى \\
\hline rir & شنيدارى \\
\hline DFF & خو اندن/نوشتن \\
\hline rYq & جنبشى \\
\hline 90. & جند كانه \\
\hline 1991 & كل \\
\hline
\end{tabular}

با توجه به نتايج، مشـخصـات بنج خوشـه در جداول r وب ارائه شــده

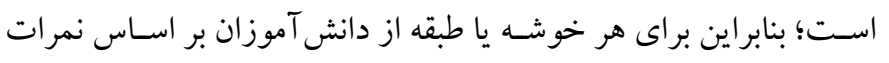

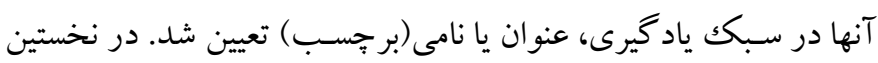

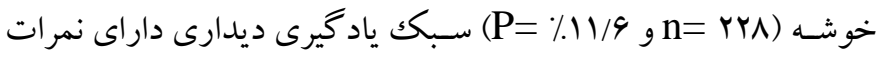

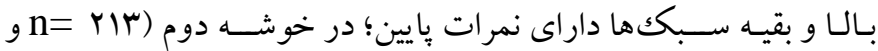

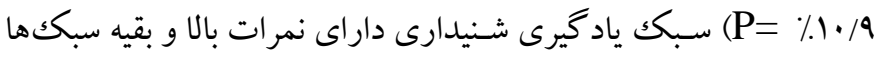

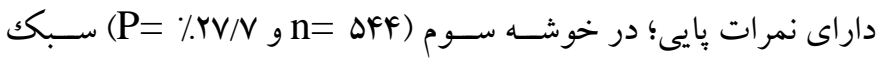

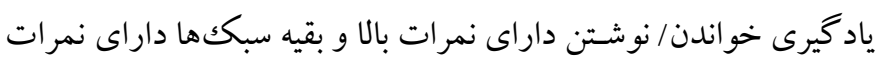

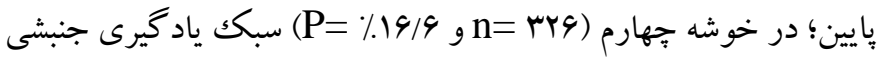

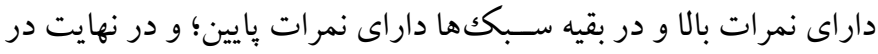

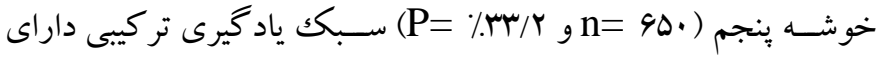


شـيدارى، كمترين ميزان را به خود اختصـاص داده اسـت. در ادامه و در

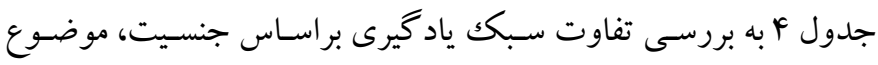
درسى، و يايه هاى تحصيلى خواهيم برداخت.
جدول بـدر واقع جدول توزيع فراوانى خوشـها را نشان مىدهد. با

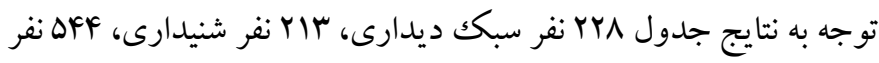

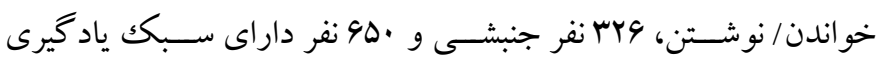

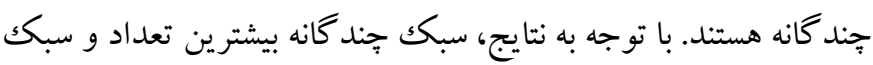

جدول ع: آزمون خى دو جهت بررسى تفاوت سبك يادكيرى بر اساس جنسيت، موضوع درسى، و بايههاى تحصيلى نوبي

\begin{tabular}{|c|c|c|c|c|c|c|c|c|c|c|c|}
\hline \multicolumn{2}{|c|}{ تر كيبى (جند كانه) } & \multicolumn{2}{|c|}{ جنبشى } & \multicolumn{2}{|c|}{ نوشتن /خواندن } & \multicolumn{2}{|c|}{ شنيدارى } & \multicolumn{2}{|c|}{ ديدارى } & & \\
\hline مورد & مورد & 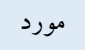 & مورد & مورد & مورد & مورد & مورد & مورد & مورد & & \\
\hline انتظار & مشاهده & انتظار & مشاهده & انتظار & مشاهده & انتظار & مشاهده & انتظار & مشاهده & & \\
\hline TYY/F & ros & $|V| N$ & 19. & YA9/9 & एव९ & $11 \% / r$ & $11 \%$ & $1 r \cdot 1$ & $1 . v$ & زن & \\
\hline$r \cdot V / 9$ & rar & $1 \Delta F / \pi$ & 199 & $r \Delta V / F$ & ${ }^{r A \wedge}$ & $\begin{array}{l}1 \cdots / A \\
19 / A V r\end{array}$ & $d f=4$ & $\begin{array}{c}1 \cdot v / q \\
p=\cdot / . .1\end{array}$ & $|r|$ & مرد ل & \\
\hline$r \Delta I / r$ & r9D & $189 /$. & 111 & $r 1 \cdot r$ & r.. & $\Delta r / r$ & ar & $M / 1$ & $\wedge 9$ & 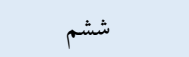 & \\
\hline $19 \Delta / r$ & r.1 & $9 \mathrm{~V} / 9$ & $\Lambda \Delta$ & $19 \pi / 4$ & $|v|$ & $9 \% /$. & 90 & $9 N / \Delta$ & $9 \mathrm{~V}$ & ينجم & بايه تحصيلى \\
\hline$r \cdot r / 9$ & MAF & $1 . r / 1$ & ir. & $i v \cdot / r$ & ${ }^{\text {inr }}$ & $\begin{array}{l}99 \mathrm{~N} \\
\text { IN/TY. }\end{array}$ & $\begin{array}{l}\Delta \Delta \\
\mathrm{df}=\Lambda\end{array}$ & $\begin{array}{c}\mathrm{v} 1 / 4 \\
\mathrm{p}=\cdot / .19\end{array}$ & vr & جهارم & \\
\hline rTV/T & m & $191 / 9$ & 199 & $\mathrm{rVT} / \mathrm{A}$ & rvI & $1 \cdot \Delta / \Lambda$ & 1.9 & $11 r / r$ & 1.9 & علوم تجربى & \\
\hline rYY/A & riv & $194 / 1$ & $1 \Delta V$ & $r V \cdot / r$ & rVr & $\begin{aligned} & 1 \cdot V / r \\
= & 1 / r .\end{aligned}$ & $\begin{array}{l}1 . v \\
d f=r\end{array}$ & $\begin{array}{l}\| / F / \Lambda \\
p=\cdot / A V A\end{array}$ & 119 & مطالعات اجتماعى & ماده درسى \\
\hline
\end{tabular}

(19)، مورفى و همكاران (IV)، ال - تانتوى (1))، و دابسون (19) مبنى بر

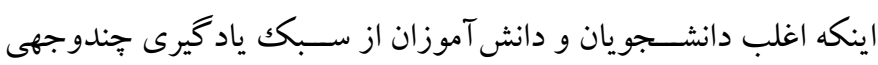

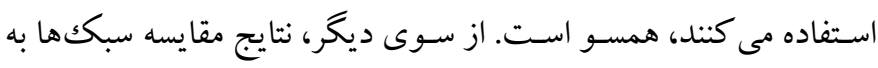
تفكيكك نشـان داد كه تفاوت معنادارى در دو جنس به لحاظ اسـتفاده از از

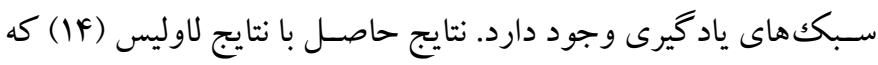
نشـان دادند سبكك ياد گيرى در بين دختران و وِر ان متفاوت است، كاملاً

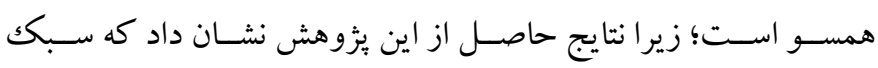

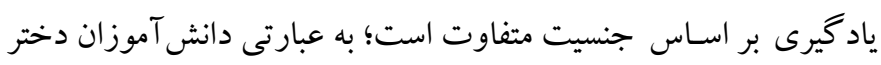

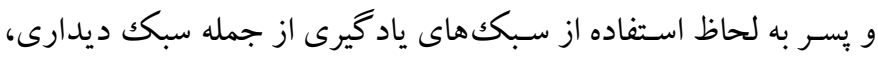

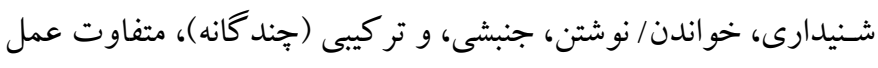

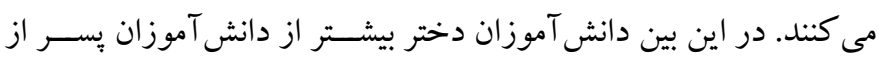

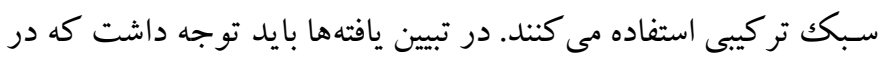

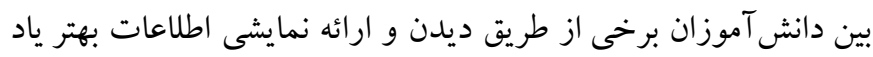

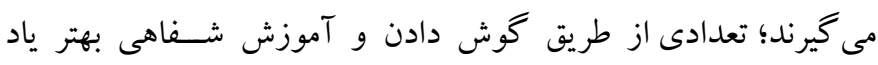

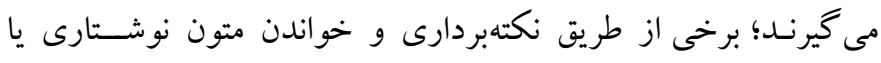

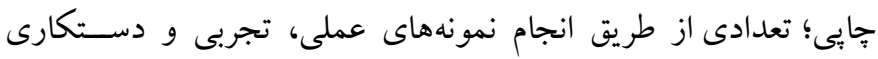

جدول F نتايج آزمون خى دو جهت بررسى تفاوت سبك يادگيرى

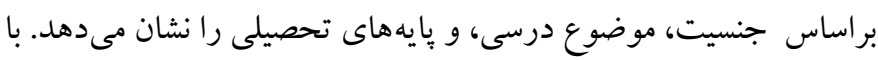

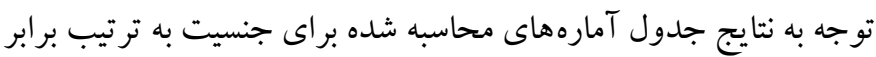

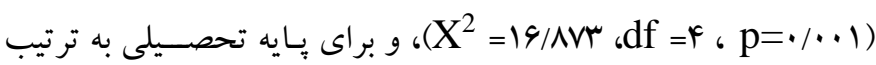

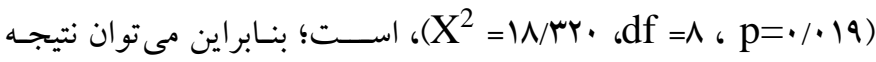
كرفت سبك ياد گيرى بر اساس جنسيت و يايه تحصيلى متفاوت است،

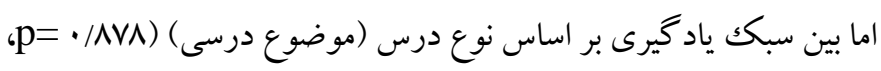

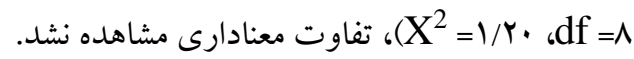

\section{بحث و نتيجه تيرى}

يزوهش حاضـر با هدف شناسايى و مقايسه سبك هاى يادگيرى برى بر اساس

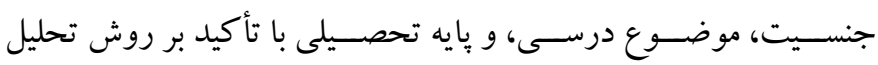

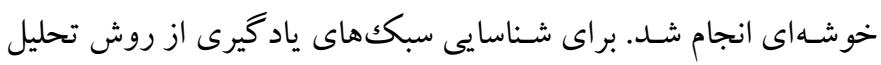

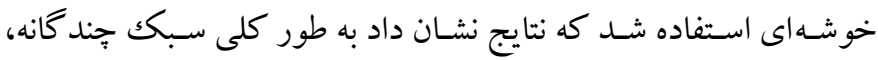
بيشترين تعداد و سبكك شنيدارى، كمترين ميزان رابه خود اختصاص داده اسـت. نتايج حاصـل با نتايج كوك و همكاران (ها)، جيمز و همكاران 
موفقيت بيشـترى در تحصسيل به دسـت آورند، ولى همه آنها نيز از

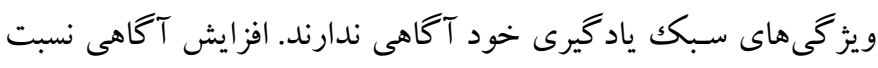

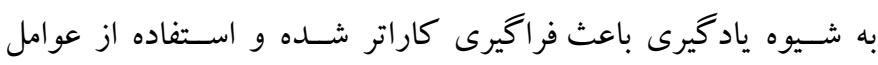

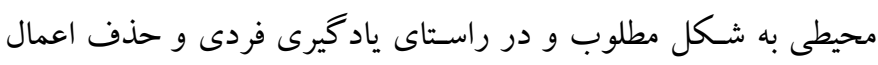
نامناسـب را سـبب مىشـود. در نتيجه مدرس بايد روشهاى ارتباطى و

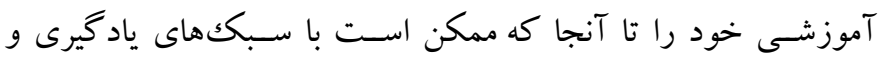
تفكر فراگيران وفق دهد تا يادگيرى هرجه بهتر و و عميقتر اتفاق افتد

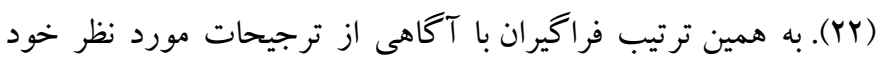

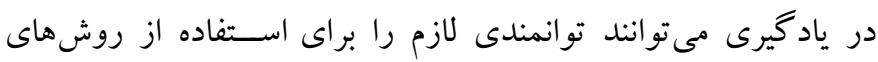
مختلف در جهت ارتقـاى يادكيرى كسـب كرده و بدين وسـيله

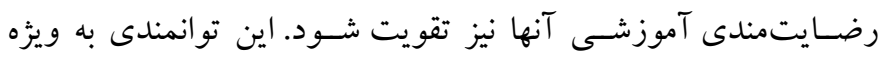

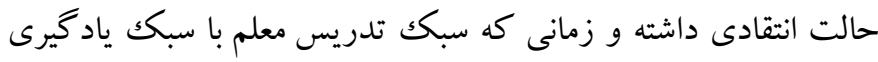
فراگير هماهنگك نيست مفيد واقع مىشود (Yr).

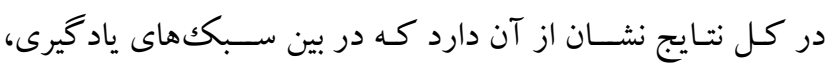
گسترد گحى متفاوتى در افراد نمونه وجود دارند؛ ولى يشستر دانش آموزان

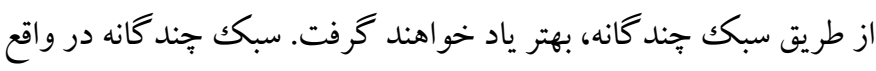

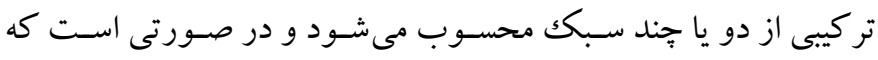

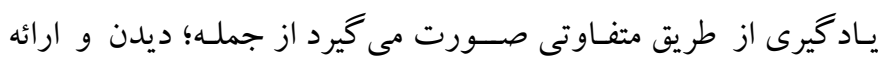

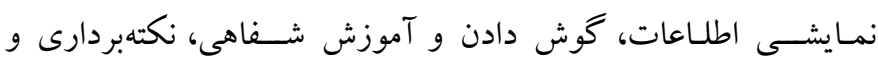

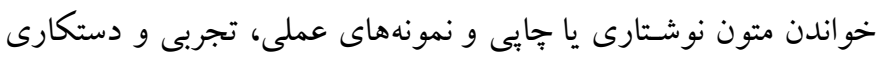

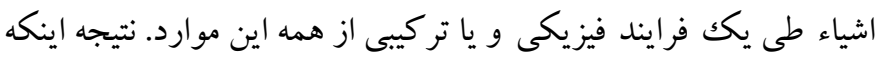

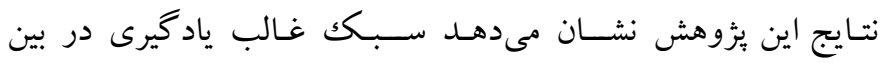

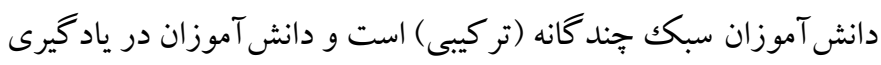
خود به طور همزمان از جندين سبكك استفاده مى كنند. بر اساس نتايج و

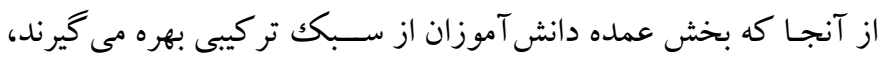

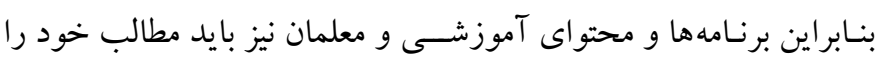

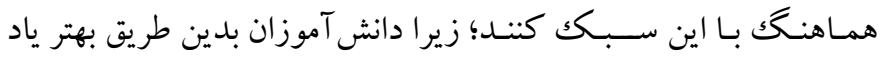
خو اهند كرفت و اثربخشى كلاس درس و همجنين نظام آموزشى بيشتر

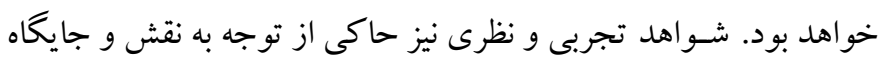

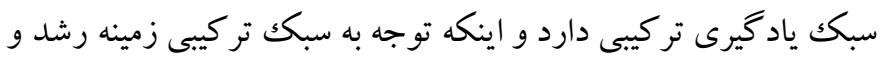

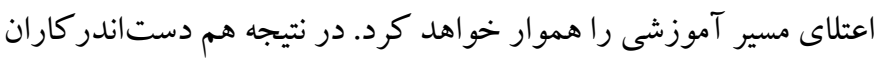

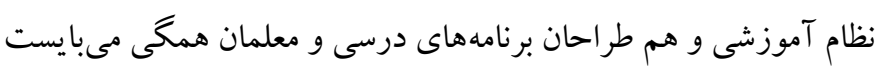

اشياء طى يكك فرايند فيزيكى بهتر ياد مى گيرند؛ و تعدادى نيز با تركيبى

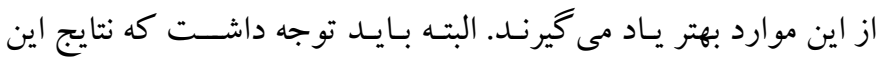

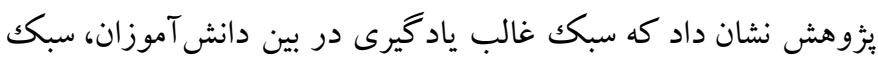

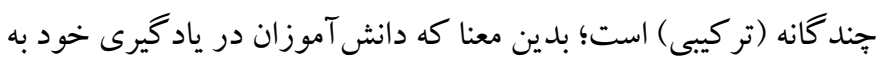
طور همزمان از جندين سبك استفاده مى كنند.

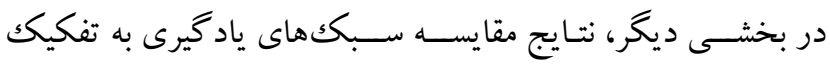

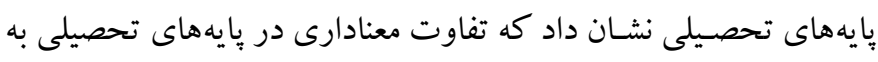

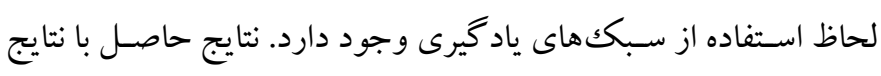

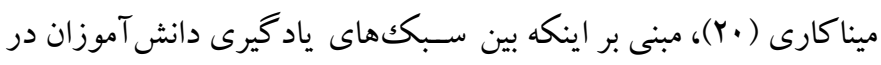

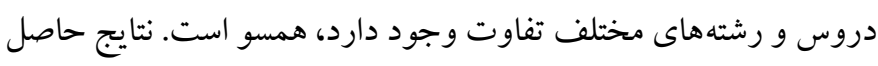

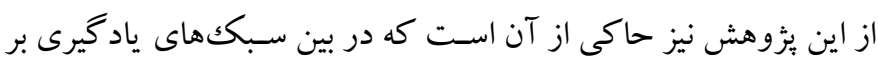

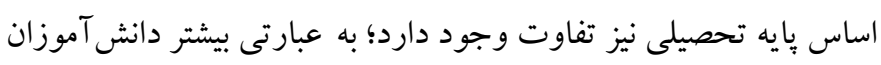
پايه ششم ابتدايى از سبك تركيبى استفاده مى كنند.

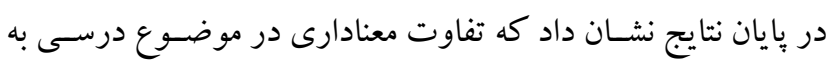

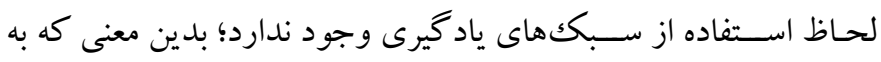

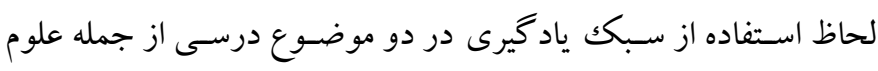

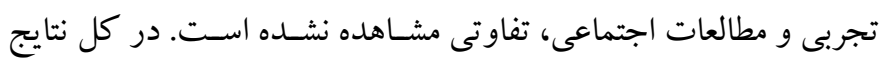

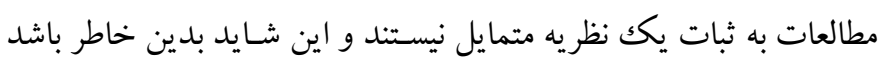

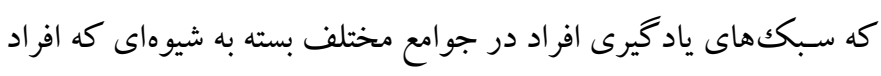

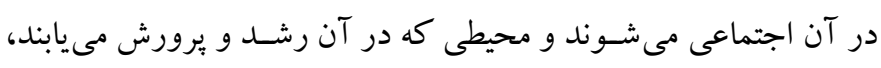

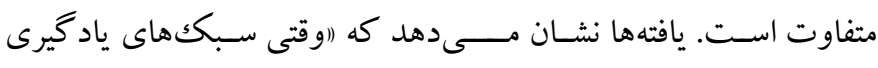

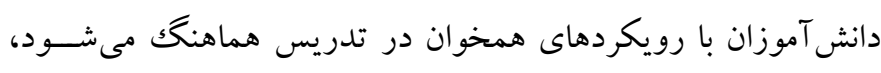

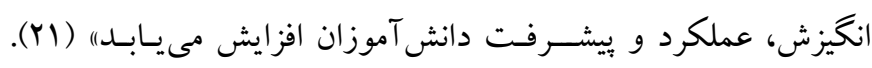

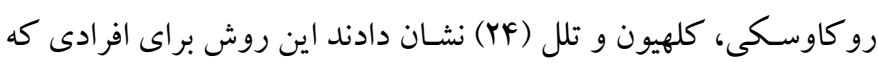

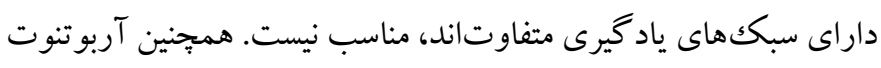

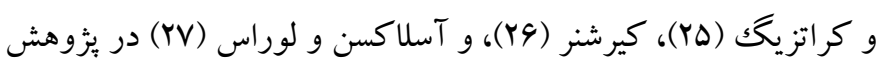
خود بر تأثير آموزش مبتنى بر سبك يادگيرى تاكيد دارند.

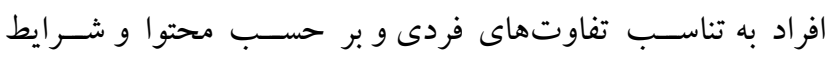

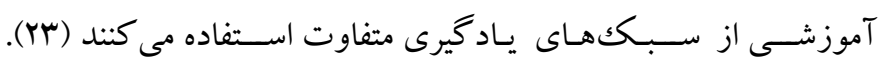

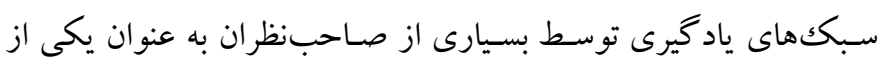

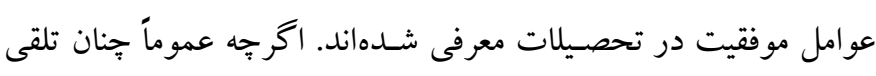

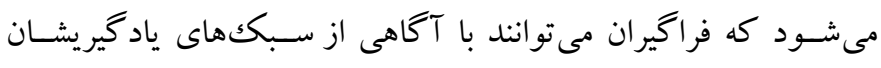


تلاش شـود اطلاعات مناسـب با هر يكك از سبككها به دانش آموزان ارائه شود؛ زيرا كه آكاهى معلمان از سبك هاى ياد گيرى دانش آموزان موجب تدريس مؤثرتر و كاهش مشكلات ياد گيرى مى شود.

ملاحظات اخلاقى ييروى از اصول اخلاق ثزوهش: اين بثزوهش بـا مجوز علمى دانشـــاه تبريز و با

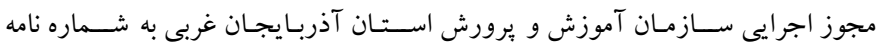
F ا

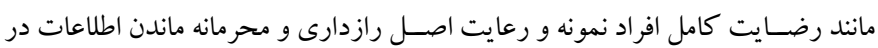
نظر گر فته شده است. حامى مالى: اين مطالعه بدون حمايت مالى هيج گَّنه سـازمان و يا مؤسسه انجام شده

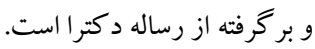

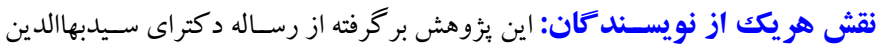
كريمى اسـت. دكتر يوسـف اديب به عنوان استاد راهنما و دكتر دكتر فيروز محمودى و دكتر رحيم بدرى گر گرى به عنوان استادان مشاور در اين مطالعه نقش داشتند. تضـاد منافع: بر اسـاس اعلام نويسند كان، در اين يُوهش هيج گونه تضاد منافع وجود

نداشته است.

تشـكر و قدردانى: از تمامى افراد نمونه، اسـتادان راهنما و مشــاور، مديران سـازمان

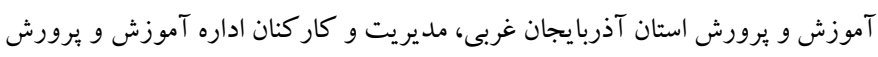

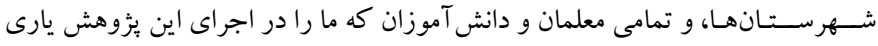
كردند، تشكر مىشود.
بـه نقش ســــككهـاى مختلف در دانش آموزان توجه كنند و در اين بين سبك تر كيبى كه مجموعهاى از سبككهاى ديخر به شمار مى آيد را بيشتر مورد توجـه قرار دهنـد. تقريبـاً همـهـ افراد از همـه راهبردهاى ياد گيرى اســتفـاده مى كنند و تفاوتهاى فردى و كروهى در ميزان و شــدت ترجيحات اســت. در اغلب مطالعات در جمعيتهاى مختلف، بيشــتر شر كت كنند كان داراى جند راهبرد ياد گيرى ترجيحى شناخته مىشوند و در طبقه راهبرد ياد گيرى جندوجهى قرار مى گيرند كه نتايج اين يُزوهش نيز مؤيد اين مسئله است.

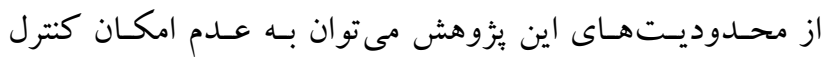
متغيرهـاى مداخله كننده مانند شـــرايط محيطى، اقتصــادى و هوش كلى آزمونشـوند كان اشـاره كرد. همجِنين دادههاى بثزوهش حاضـر فقط از طريق برسـشنامه جمع آورى شده است و از روش ها و تكنيككهاى ديخر اسـتفاده نشـده است. جِنين روش مستقيمى ممكن است موجب سو گيرى آزمونشوند كان در يِاسخگ يَى به سؤالهاى آزمون شده و از دقت نتايج آن بكاهد. در نتيجه بيشـنهاد مىشـود كه در يزوهش هاى بعدى از سـاير تكنيككها و ابزارها از جمله مصاحبه و مشاهده نيز استفاده شود. همجنين اين بيزوهش در ساير كروههاى آمارى و با كنترل متغيرهاى مداخله كننده از قبيل شـرايط محيطى، اقتصـادى و هوش مورد بررسـى قرار كيرد. در نهايت يِشنهاد مى شود ضمن شناخت بهتر سبك ياد كيرى دانش آموزان، 


\section{References}

1. Steyn T, Maree J. A profile of first-year students' learning preferences and study orientation in mathematics [Conference Paper]. [Heronissos, Greece]: Second International Conference for the teaching of Mathematics (ICTM2); 2002, pp: 1-10. [Link]

2. Sreenidhi SK, Tay Chinyi H. Styles of learning based on the research of rernald, Keller, Orton, Gillingham, Stillman, Montessori and Neil D Fleming. International Journal for Innovative Research in Multidisciplinary Field. 2017; 3(4): 17-25. [Link]

3. Rogers TB. The psychological testing enterprise: An introduction. Pacific Grove, Calif: Brooks/Cole Pub Co; 1994, pp: 45-51. [Link]

4. Homayouni A, Ebrahimi Ghavam S. Relationship between learning styles and metacognitive processes with mathematics anxiety in financial sciences students. International Journal of Research in Organizational Behavior and Human Resource Management. 2014; 2(3): 34-42. [Link]

5. Atkinson S. Cognitive style in the context of design and technology Project work. J Educ Psychol. 1998, 18(2): 183-194. [Link]

6. Fleming ND. Teaching and learning styles: VARK strategies. IGI Global; 2011, pp: 78-85. [Link]

7. Siriopoulos C, Pomonis G. Learning style changes and their relationship to critical thinking skills. J Coll Teach Learn. 2007; 4(1): 45-60. [Link]

8. Willingham DT, Hughes EM, Dobolyi DG. The scientific status of learning styles theories. Teach Psychol. 2015; 42(3): 266-271. [Link]

9. Newton PM, Miah M. Evidence-based higher education - is the learning styles 'Myth' important? Front Psychol. 2017; 8: 444. [Link]

10. Coffield F, Moseley D, Hall E, Ecclestone K. Learning styles and pedagogy in post-16 learning: A systematic and critical review. London, UK: Learning \& Skills Research Centre; 2014, pp: 41-82. [Link]

11. Salimi M, Sadeghifar J, Peyman H, Shams L, Jandagheian M, Khosravi A, et al. Visual, aural, $\mathrm{read} / \mathrm{write}$, and kinesthetic learning styles preferences in students of Isfahan University of Medical Sciences, Iran. Health System Research. 2012; 8(7): 1216-1224. [Persian]. [Link]

12. Fang AL. Utilization of learning styles in dental curriculum development. N Y State Dent J. 2002; 68(8): 34-38. [Link]
13. Bailey P, Onwuegbuzie AJ, Daley CE. Using learning style to predict foreign language achievement at the college level. System. 2000; 28(1): 115-133. [Link]

14. Lovelace MK. Meta-analysis of experimental research based on the Dunn and Dunn model. J Educ Res. 2005; 98(3): 176-183. [Link]

15. Koch J, Salamonson Y, Rolley JX, Davidson PM. Learning preference as a predictor of academic performance in first year accelerated graduate entry nursing students: A prospective follow-up study. Nurse Educ Today. 2011; 31(6): 611-616. [Link]

16. James S, D'Amore A, Thomas T. Learning preferences of first year nursing and midwifery students: Utilising VARK. Nurse Educ Today. 2011; 31(4): 417-423. [Link]

17. Murphy RJ, Gray SA, Straja SR, Bogert MC. Student learning preferences and teaching implications. J Dent Educ. 2004; 68(8): 859-566. [Link]

18. El-Tantawi MM. Factors affecting postgraduate dental students' performance in a biostatistics and research design course. J Dent Educ. 2009; 73(5): 614623. [Link]

19. Dobson JL. A comparison between learning style preferences and sex, status, and course performance. Adv Physiol Educ. 2010; 34(4): 197-204. [Link]

20. Minakari M. Investigation of psychometric characteristics of isalem-97 and comparison of cognitive learning styles in university students. Contemporary Psychology. 2006; 1(1): 29-39. [Persian]. [Link]

21. Kang S. Learning styles: Implications for ESL/EFL instruction. Forum. 1999; 37(4): 6. [Link]

22. Pazargadi M, Tahmasebi S. Learning styles and their application in nursing. Education Strategies in Medical Sciences. 2010; 3(2): 73-76. [Persian]. [Link]

23. Karimi Moonaghi H, Dabbaghi F, Oskouie F, Vehviläinen-Julkunen K. Learning style in theoretical courses: nursing students' perceptions and experiences. Iranian Journal of Medical Education. 2009; 9(1): 41-54. [Persian]. [Link]

24. Rogowsky, B A,.Calhoun, B $\mathbf{M}$ and Tallal, P. Providing Instruction Based on Students' Learning Style Preferences Does Not Improve Learning. Educational Psychology, 2020, 11, 64. [Link]

25. Arbuthnott, K. D., and Kratzig, G. P. Effective teaching: sensory learning styles versus general memory processes. Innovative Teach. 2015 4, 1-9. [Link]

26. Kirschner, P. A. Stop propagating the learning styles myth. Comp. Educ. 2017, 106, 166-171. [Link] 
27. Aslaksen, K., and Loras, H. The modality-specific learning style hypothesis: a mini review. Front. Psychol. 2018, 9, 1-5. [Link]

28. Safari Y, Bazrafshan A. An investigation into the relationship between shirazhigh school student's learning styles and educational. Journal of New Approaches in Educational Administration. 2010; 1(2): 17-30. [Persian]. [Link]

29. Duff A. The role of cognitive learning styles in accounting education: Developing learning competencies. Journal of Accounting Education. 2004; 22(1): 29-52. [Link]

30. Armstrong E, Parsa-Parsi R. How can physicians' learning styles drive educational planning? Acad Med. 2005; 80(7): 680-684. [Link]
31. Ahanchian M, Mohamadzadeghasr A, Garavand H, Hosseini A. Prevalent learning styles among nursing and midwifery students and its association with functionality of thinking styles and academic achievement a study in mashhad school of nursing and midwifery. Iranian Journal of Medical Education. 2012; 12(8): 577-588. [Persian]. [Link]

32. Romanelli F, Bird E, Ryan M. Learning styles: A review of theory, application, and best practices. Am J Pharm Educ. 2009; 73(1): 09. [Link]

33. Amini N, Zamani BE, Abedini Y. Medical students' learning styles. Iranian Journal of Medical Education. 2010; 10(2): 141-147. [Persian]. [Link] 